\title{
Association of Tissue Factor Activity with the Surface of Cultured Cells
}

\author{
J. R. Maynard, C. A. Heckman, F. A. Pitlick, and Y. Nemerson \\ From the Departments of Internal Medicine and Molecular Biophysics \\ and Biochemistry, Yale University School of Medicine, \\ New Haven, Connecticut 06510
}

\begin{abstract}
A B S TRACT Tissue factor occurs in a dormant state on the surface of cultured normal human fibroblasts and WISH ${ }^{1}$ amnion cells. The activity of undisturbed monolayers or cells lifted with brief trypsin treatment $(0.125 \%$ trypsin for $1 \mathrm{~min})$ increases up to 60 -fold upon prolonged digestion with dilute trypsin $(0.0025 \%$ trypsin for $30 \mathrm{~min}$ ); activity appears subsequent to cell detachment. Up to $70 \%$ of the total cellular tissue factor becomes active under these conditions and is released from the cells. The ruthenium red staining coat of the cells is lost during detachment, but cell viability (more than 90\% exclude trypan blue) and cell morphology do not change during the subsequent development of tissue factor activity. Furthermore, less than $10 \%$ of four intracellular enzymes and less than $20 \%$ of two plasma membrane enzymes are released during this period of time. We therefore conclude that cells in culture do have tissue factor activity, that it exists in a latent form, and that total cell disruption is not necessary for this activity to initiate blood coagulation.
\end{abstract}

\section{INTRODUCTION}

Blood coagulation occurs in vivo only after blood vessels are injured. It has been generally held that the endothelium is inert towards the coagulation system and acts as a barrier between the activators of coagu-

A preliminary report of this work was presented to the Federation of American Societies of Experimental Biology, Atlantic City, N. J., and appears in abstract form, 1974 (Fed. Proc. 33 : 243).

Received for publication 4 October 1974 and in reiised form 16 December 1974.

${ }^{1}$ The established cell lines used in these studies are WISH, a cell line derived from human amnion tissue; MDBK, a cell line derived from steer kidney; and HeLa, a cell line derived from a human carcinoma. Characteristics of these cells are described in "Registry of Animal Cell Lines" from the American Type Culture Collection. lation and circulating coagulation factors (see Kirk [1] for example).

There are two pathways by which coagulation may be initiated. In one, the intrinsic system, the first event is activation of Hageman factor which is due to the interaction of this factor with collagen or other types of connective tissues $(2,3)$. The second pathway, the tissue factor or extrinsic system, is initiated when a membrane-bound lipoprotein, tissue factor, forms an enzymatically active complex with factor VII, a plasma protein (4-6). This complex proteolytically attacks factor $\mathrm{X}$ (7) leading to the formation of activated factor $\mathrm{X}$ which then directly converts prothrombin to thrombin (8).

Collagen is clearly remote from the vessel lumen (9), and the endothelium may indeed act as an inert barrier to activation of the intrinsic pathway; however, tissue factor appears to be in or on the plasma membranes of many cell types including endothelial cells. In fact, in previous studies in which immunohistochemical methods were used to localize tissue factor, endothelial cells appeared to stain more intensely than any other cell type $(10,11)$. As it is generally agreed that there is little if any continuous in vivo coagulation, it follows that if tissue factor is on the surface of endothelial cells, a mechanism must exist for maintaining tissue factor in a protected or latent state. We have chosen to examine the question of latency by determining the availability of tissue factor in cells grown in culture. To facilitate these experiments, we have used normal human fibroblasts, cells previously described to have tissue factor activity $(12,13)$, and the established line of WISH amnion cells as model systems.

Others have shown that fully disrupted cultured cells (for example, fibroblasts [12,13], monkey kidney cells and Chang liver cells [12], and lymphocytes [14]) have tissue factor activity. In the experiments we present 
here, we show that while this is indeed the case, unperturbed cells express little or no activity. Furthermore, we show that incubation of the cells with proteolytic enzymes, using conditions that completely preserve cell viability, leads to the expression of most of the tissue factor activity of these cells. From these observations we conclude that, in the cells studied, a significant proportion of the tissue factor occurs external to the plasma membrane but is protected from interaction with plasma coagulation factors, perhaps by the mucopolysaccharide-containing cell-surface coat (15-17). Thus, in a model system, tissue factor is shown to be latent, and therefore we have established in principle that tissue factor can be present in cells in contact with the blood without initiating blood coagulation.

\section{METHODS}

Materials. Trypsin, chymotrypsin, bovine serum albumin, soybean trypsin inhibitor, neuraminidase, elastase, hyaluronidase, $\beta$-galactosidase, papain, pronase, mucin, fibrinogen, and cytochrome $c$ were purchased from Sigma Chemical Co., St. Louis, Mo. Crude collagenase (125-200 U/mg from Clostridium histolyticum) and neuraminidase $(0.5 \mathrm{U} / \mathrm{mg}$ from Clostridium perfingens) were products of Worthington Biochemical Corp., Freehold, N. J. Five-times crystallized ovalbumin and lyophilized bovine plasma were products of Miles Laboratories, Inc., Elkhart, Ind. All enzymes were of the highest purity of the respective suppliers.

Fetal calf serum, nonessential amino acid supplement $(100 \times$ concentrate $)$, trypan blue, minimal essential medium with Eagle's salts (MEME)², sterile, buffered saline (Saline A), streptomycin, and penicillin were products of Grand Island Biological Co., Grand Island, N. Y. N-2-Hydroxyethylpiperazine- $N$-2-ethanesulfonic acid (HEPES), EDTA, AMP, p-nitrophenylphosphate, NADH, NADP, NADPH, glucose-6-phosphate, cadavarine, $p$-hydroxyphenyl acetic acid, and Tris were purchased from Sigma Chemical Co. Ruthenium red and practical grade aminooxanilic acid were products of $\mathrm{K} \& \mathrm{~K}$ Laboratories, Inc., Plainview, N. Y. Thiocarbohydrazide was obtained from Eastman Organic Chemicals Div. Eastman Kodak Co., Rochester, N. Y., and silver proteinate was from Polysciences Inc., Warrington, $\mathrm{Pa}$. Pyruvic acid was purchased from Calbiochem, La Jolla, Calif., and Sepharose 6B was obtained from Pharmacia Fine Chemicals Inc., Piscataway, N. J. Other reagents were analytical grade and obtained from the usual sources.

Plastic petri dishes were products of Falcon Plastics, Division of BioQuest, Oxnard, Calif. Glass flat bottles $\left(150 \mathrm{~cm}^{2}\right)$ were purchased from Keystone Bottle Co., New Haven, Conn.; roller bottles $\left(600 \mathrm{~cm}^{2}\right)$ were products of Bellco Glass Inc., Vineland, N. J., and $0.2 \mu \mathrm{m}$ filters were a product of Nalge Co., Nalgene Labware Div., Rochester, N. Y. WISH amnion cells and human fibroblasts were obtained from the American Type Culture Collection, Rockville, Md.; fibroblasts were also a gift from Dr. Thomas Gelehrter.

${ }^{2}$ Abbreviations used in this paper: HEPES, N-2-Hydroxyethyl piperazine- $N$-2-ethanesulfonic acid; MEME, minimal essential medium with Eagle's salts; Saline A, sterile, buffered saline.
Factor VII was purified by the method of Jesty and Nemerson (7). Factor $\mathrm{X}$ and prothrombin were purified by the method of Esnouf, Lloyd, and Jesty (18). A crude phospholipid emulsion ("cephalin") was prepared by the method of Bell and Alton (19). The preparation of EDTA-brain has been previously described (4). Factor VII-deficient plasma was prepared from lyophilized bovine plasma by the method of Nemerson and Clyne (20).

Cell culture techniques. Normal skin fibroblasts from an adult male and the established line of WISH amnion cells were maintained in a growth medium of MEME supplemented with glutamine $(292 \mathrm{mg} /$ liter $)$, penicillin $(50 \mathrm{U} / \mathrm{ml})$, streptomycin $(50 \mu \mathrm{g} / \mathrm{ml})$, nonessential amino acid supplement, (Grand Island Biological Co., 1:100 dilution), and $10 \%$ fetal calf serum.

Approximately $24 \mathrm{~h}$ before each experiment, the cells were dispersed by incubating the washed monolayer with $0.2 \%$ trypsin for $5 \mathrm{~min}$. All enzyme concentrations are expressed as a weight/volume percent. The cells were subcultured 1:2 into fresh medium substituted with adsorbed fetal calf serum.

Adsorbed fetal calf serum. To remove coagulation factors II, VII, IX, and $\mathrm{X}$, fetal calf serum was adsorbed with 30 $\mathrm{mg} / \mathrm{ml}$ of dry-heat sterilized $\mathrm{Ca}_{10}(\mathrm{OH})_{2}\left(\mathrm{PO}_{4}\right)_{6}$ for $1 \mathrm{~h}$ and then filtered through a $0.2 \mu \mathrm{m}$ Nalge (Nalge Co., Nalgene Labware Div.) filter apparatus.

Cell suspensions prepared with trypsin. After removal of the adsorbed serum growth medium, the monolayer was washed once with Saline A containing 0.02 M HEPES buffer, $\mathrm{pH} 7.4$ (Saline A/HEPES). The washed monolayer in each bottle $\left(150 \mathrm{~cm}^{2}\right)$ was incubated with $2.0 \mathrm{ml}$ of $0.125 \%$ trypsin in Saline A/HEPES at room temperature for $1 \mathrm{~min} .10 \mathrm{ml}$ of $0.025 \%$ soybean trypsin inhibitor in Saline A/HEPES was added to stop the reaction, and the loosened cells were dispersed from their growth support by pipetting.

Proteolytic treatment and separation of cell coat fraction. Enzyme concentrations were adjusted to be low enough that they would not interfere with the two-stage tissue factor assay. For most experiments involving the WISH amnion cells, $100-\mu 1$ of a cell suspension of $10^{6}$ cells $/ \mathrm{ml}$ were assayed for tissue factor activity; for the experiments using normal fibroblasts, the concentration of suspended cells was approximately $2 \times 10^{5}$ cells $/ \mathrm{ml}$. Cell viability was determined by trypan blue exclusion (21). The cells were suspended in Saline A/HEPES and incubated for the indicated times in $0.0025 \%$ trypsin or $0.00125 \%$ chymotrypsin. These proteolytic enzymes retain full activity under the conditions employed to enhance tissue factor activity.

The cell-free supernate from the tryptic digest was partially purified by layering the digest over a sucrose solution $(0.95 \mathrm{M}$ sucrose in $0.05 \mathrm{M}$ cacodylate, $\mathrm{pH} \mathrm{7.2,d} \mathrm{1.12)} \mathrm{and}$ centrifuging for $90 \mathrm{~min}$ at $94,000 \mathrm{~g}$ in an SW27 rotor (Beckman Instruments Inc., Fullerton, Calif.). Particulate material containing tissue factor layered at the sucrose interface; whole cells and cellular debris were found in the pellet.

Tissue factor assay. Tissue factor activity was assayed using a two-stage technique. In the first stage, $100 \mu \mathrm{l}$ tissue factor (EDTA-brain standard or cell suspension) was mixed with $100 \mu 10.025 \mathrm{M} \mathrm{CaCl}_{2}$ and $100 \mu 1$ factor VII $(125 \mathrm{U} / \mathrm{ml})$ in $0.05 \mathrm{M}$ Tris, $0.1 \mathrm{M} \mathrm{NaCl}, \mathrm{pH} \mathrm{7.4,} \mathrm{containing} \mathrm{bovine} \mathrm{serum}$ albumin $(2 \mathrm{mg} / \mathrm{ml})$ to stablize factor VII, and soybean trypsin inhibitor $(25 \mu \mathrm{g} / \mathrm{ml})$ to inhibit the trypsin $(0.0025 \%)$ used to deveolp tissue factor activity. None of the additives in the factor VII reagent had any effect upon the assay at the concentrations employed. After $3 \mathrm{~min}$ at $37^{\circ} \mathrm{C}, 100 \mu \mathrm{l}$ 
of this preincubation mixture was mixed with a second $100 \mu \mathrm{l}$ of $0.025 \mathrm{M} \mathrm{CaCl}_{2}$, and then $100 \mu \mathrm{l}$ of factor VIIdeficient plasma (20) was added. The clotting time was compared with a standard curve prepared by dilution of the EDTA-bovine brain standard used in this laboratory (22).

This assay is more convenient than that previously described (22) and has similar sensitivity. Specificity was demonstrated by substituting a buffer blank for factor VII; the clotting times were then equivalent to those obtained without tissue factor.

Generation of thrombin using purified coagulation factors. Cells were transferred to $60-\mathrm{mm}$ petri dishes and were allowed to grow for approximately $20 \mathrm{~h}$ in the absorbed serum media described above. The cell yield was in the range $5 \times 10^{5}-1 \times 10^{8}$ cells per plate. The monolayer was washed once with Saline A/HEPES, and then $2.0 \mathrm{ml}$ of this same buffer was added per plate. To the buffer was added $20 \mu \mathrm{l}$ cephalin suspension, $50 \mu \mathrm{l}$ prothrombin $(3 \mathrm{mg} /$ $\mathrm{ml}), 10 \mu \mathrm{l} 1 \mathrm{M} \mathrm{CaCl}, 5 \mu \mathrm{l}$ factor VII $(50,000 \mathrm{U} / \mathrm{ml})$, and $5 \mu \mathrm{l}$ factor $\mathrm{X}(0.4 \mathrm{mg} / \mathrm{ml})$. Each component was added separately and at a different location in the petri dish. The reaction was started by swirling the solution to mix the reagents. $100-\mu 1$ samples were removed from the supernate of the intact monolayer and assayed for thrombin by addition to $200 \mu \mathrm{l}$ fibrinogen $(10 \mathrm{mg} / \mathrm{ml}$ in Tris saline). This activity was compared with that generated by a similar plate of cells that had been frozen in dry-ice ethanol and thawed (three times) before the addition of the prothrombin mixture.

The amount of thrombin generated was dependent upon the time of incubation and the tissue factor activity. The results are expressed as the amount of thrombin generated in a fixed time as determined from a standard thrombin dilution curve where $100 \%$ is equivalent to $2 \mathrm{NIH} \mathrm{U/ml}$. A dilution of freeze-thaw-treated cells produced a decrease in tissue factor activity proportional to the dilution, and a cellfree control reaction had no tissue factor activity as shown by the lack of any thrombin generation.

The cell number for the monolayer was estimated by counting the cells released by $0.0025 \%$ trypsin from a duplicate monolayer. Virtually all of the cells were released into suspension.

Purification of neuraminidase. An affinity column similar to that described by Cuatrecasas and Illiano (23) was prepared. Cadavarine and then $p$-hydroxyphenyl acetic acid were coupled to Sepharose 4B beads by standard methods (24). $p$-Aminooxanilic acid was dissolved in water by titration to $\mathrm{pH} 7.0$ with $\mathrm{NaOH}$. After decolorization with Norit neutral decolorizing carbon (Fisher Scientific Co., Pittsburgh, $\mathrm{Pa}$.), the $\mathrm{pH}$ of this solution was lowered to 4.5 with glacial acetic acid. A $300-\mathrm{mg}$ sample of the damp white precipitate was diazotized (24) and added to the Sepharose-cadavarine- $p$-hydroxyphenol acetic acid beads. After washing with water to remove the excess reagents, a $0.4 \times 6-\mathrm{cm}$ column was prepared and eluted as described by Cuatrecasas and Illiano (23). Neuraminidase activity was measured by the release of sialic acid from mucin using the method of Warren (25).

Assay's for relcase cellular enzymes. Cells were suspended by brief trypsinization and washed as described above, and suspended in Saline A/HEPES at concentrations of $1-5 \times 10^{6}$ cells $/ \mathrm{ml}$. Trypsin was added to the suspension to a final concentration of $0.0025 \%$. The cells were then divided among separate tubes, and the trypsin activity was stopped at various times by addition of an equimolar amount of soybean trypsin inhibitor. The suspension was then assayed for tissue factor activity. The cells were removed from the suspension by centrifugation at $800 \mathrm{~g}$ for $5 \mathrm{~min}$, and the resulting supernate was assayed for the level of cellular enzyme.

NADPH-cytochrome $c$ reductase activity was assayed by a modification (26) of the method of Williams and Kamin (27). 5'-nucleotidase was assayed by the method of Young (28) using 5-mM AMP and a 2-min preincubation in EDTA. Inorganic phosphate was then estimated by the procedure of Chen, Tobibara, and Warner (29). Assays for lactate dehydrogenase (30), glucose-6-phosphate dehydrogenase (31), and acid and alkaline phosphatase (32) activities were used without modification. The total level of each of these enzymes present in the cells was determined by either freeze-thawing or sonicating the cells before assay. When disrupted cells were incubated for $30 \mathrm{~min}$ with $0.0025 \%$ trypsin, no change in the activity of the plasma membrane-bound or intracellular enzymes was observed.

Electron microscopy. To examine the cell-surface coat before and after proteolytic treatment, the cultured cells were processed for electron microscopy while still attached to plastic petri dishes (33), after brief trypsinization, and after development of tissue factor activity with $0.0025 \%$ trypsin. The cells were fixed in glutaraldehyde and stained with purified ruthenium red as described by Luft (34). After dehydration in a series of increasing ethanol concentrations, the cells were embedded in a mixture of two parts Spurr resin (35) to one part of a standard Epon 8:2 resin mixture, Electron Microscopy Sciences, Fort Washington, $\mathrm{Pa}$. (36). Samples of polystyrene dishes were embedded in the same fashion.

Thin sections were cut with a diamond knife on a PorterBlum MT-1 microtome and were mounted on copper grids. After staining with saturated aqueous uranyl acetate and lead citrate (37), the grids were examined in the Hitachi HU 11-B electron microscope (Hitachi Perkin Elmer, Wilton, Conn.).

Carbohydrate residues were visualized in the WISH cells using a periodate oxidation technique. After fixation in a freshly prepared $4 \%$ formaldehyde solution containing $0.1 \mathrm{M}$ cacodylate, $\mathrm{pH} 7.2,0.1 \mathrm{M}$ glucose, $0.02 \mathrm{M} \mathrm{CaCl}_{2}$, and $0.04 \mathrm{M} \mathrm{MgCl}$, the cells were embedded in the Epon-resin mixture (Electron Microscopy Sciences) and sectioned as above. After mounting on gold grids, the sections were processed with periodic acid, thiocarbohydrazide, and silver proteinate according to the method of Thiery (38). Controls were processed in a similar manner without periodic acid oxidation.

\section{RESULTS}

Prothrombin actization by cells growing in a monolayer. To determine if undisturbed cultured cells have tissue factor availab!e on their surface, cell monolayers were washed and then incubated with factors VII, X, prothrombin, and calcium. A phospholipid emulsion (cephalin) was also added to ensure that tissue factor and not phospholipid was rate limiting in this prothrombin activation. At intervals, samples of the supernate were withdrawn from the petri dishes and assayed for thrombin activity (Fig. 1). The apparent level of tissue factor in these undisturbed cells was compared with that in the same number of cells that were either 


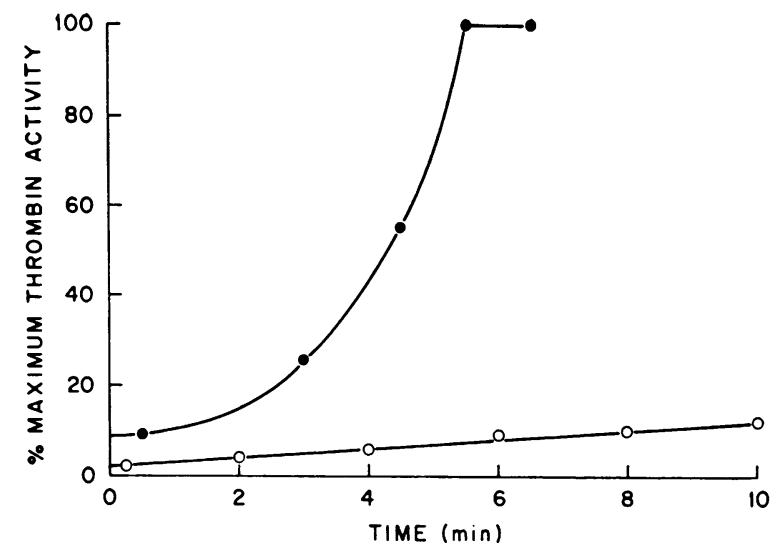

Figure 1 Activation of the extrinsic pathway by WISH amnion cells. An undisturbed monolayer $(O)$ or cells which had been previously lifted and frozen and thawed $(\bullet)$ were incubated with purified coagulation factors necessary for prothrombin activation as described in Methods. At the intervals noted, the mixture was assayed for thrombin. The cell count for the monolayer was estimated assuming the number of cells lifted from a duplicate petri dish was equivalent.

scraped off the growth support and subjected to freezethawing or frozen and thawed directly in the petri dish before the addition of the clotting zymogens.

The results of these assays were quantified by comparison with a dilution curve of thrombin. The activity of the native WISH cells was found to be approximately $10 \%$ of that of the disrupted cells $(100 \%=2$ $\mathrm{NIH} \mathrm{U})$. With fibroblast monolayers, the untraumatized monolayer had less than $5 \%$ of the activity of disrupted cells.

Effects of proteolysis on the tissue factor actizity of monolayer cells. Another approach used to study the availability of tissue factor in cultured cells was to treat the cells with proteolytic enzymes. Treatment of intact monolayers with proteolytic enzymes further substantiates the observation that tissue factor exists in the native cell in an unreactive state.

The effect of trypsin treatment on WISH cells in a monolayer (Fig. 2) showed that these cells were released from their growth support by the action of trypsin before exhibiting maximal tissue factor activity. Cell viability was measured by trypan blue exclusion and found to be greater than $97 \%$ throughout this experiment. The apparent tissue factor level in the cell suspension increased over 60 -fold during the trypsinization. While trypsin lifted the cells from the intact monolayer and enhanced the tissue factor activity of the suspension, chymotrypsin neither lifted these cells nor increased the activity in the solution over the cells.

Fibroblasts behaved somewhat differently. Undisturbed monolayers of fibroblasts had even less tissue

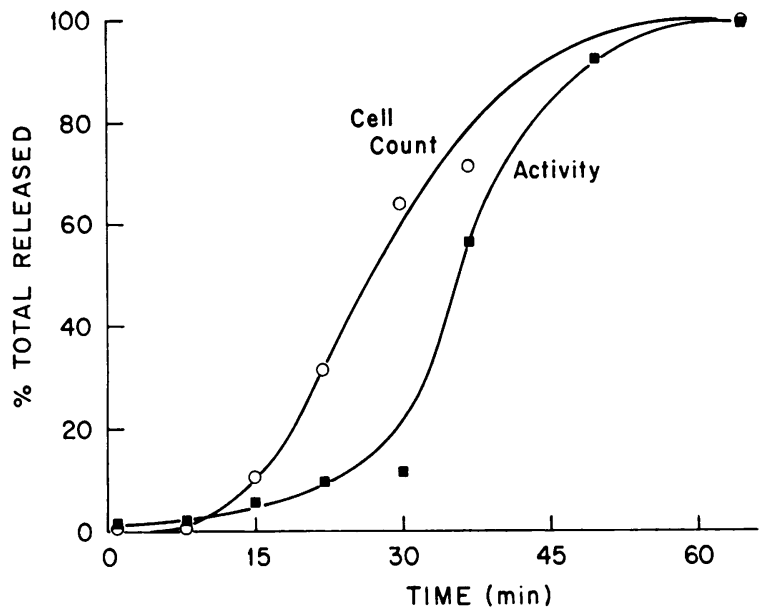

Figlre 2 Detachment of WISH amnion cells from their growth support and development of tissue factor activity. The time-course of release of cells $(O)$ during treatment with $0.0025 \%$ trypsin is compared with development of tissue factor activity in the suspension ( $\boldsymbol{\square})$.

factor activity than WISH anmion cells. Both pronase and chymotrypsin quantitatively lift the fibroblasts and produce an increase in tissue factor activity (Fig. 3). Although trypsin was less effective than these other enzymes, it did increase the apparent level of tissue factor activity (Fig. 3) also, without loss of cell viability.

Effects of enzyme treatments on tissue factor activity of trypsin-suspended cells. The studies on monolayer cells established that little or no tissue factor is available at the cell surface. To determine the extent to which cells must be damaged to express their tissue factor activity, we compared several lifting techniques

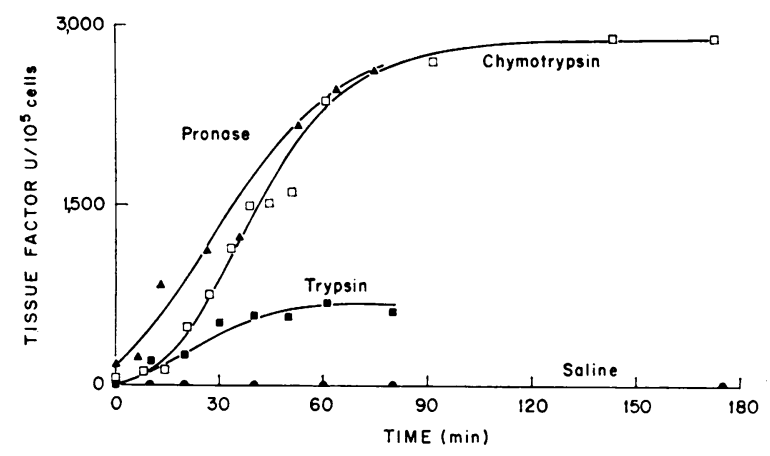

Figure 3 Release of tissue factor activity from monolayers of human fibroblasts. $0.0025 \%$ trypsin ( $), 0.00125 \%$ chymotrypsin $(\sqsupset)$, and $0.001 \%$ pronase $(\boldsymbol{\Delta})$ each released tissue factor from the monolayer into the cell suspension. Cell counts were determined for each proteolytic treatment and these numbers were used to calculate the specific tissue factor activity. Chymotrypsin and trypsin released a similar number of cells, but the activity of the chymotrypsin-treated cells was greater. 


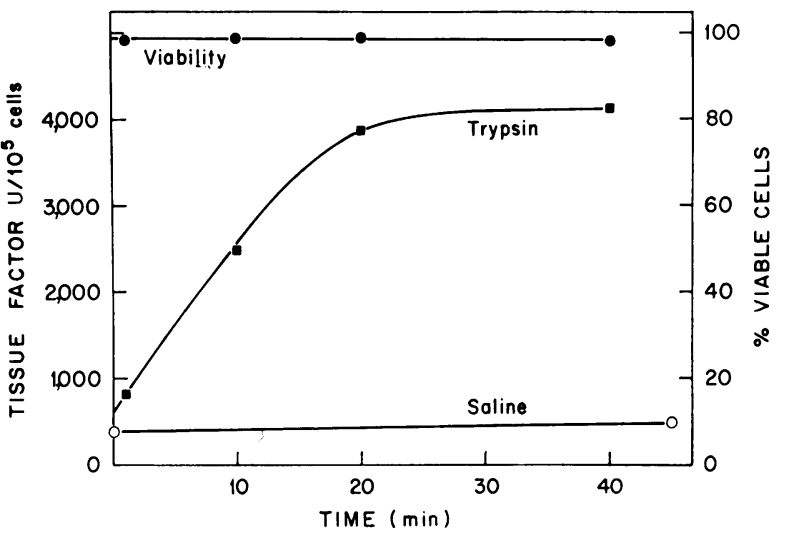

FIgURE 4 Appearance of tissue factor activity during trypsin treatment of suspended normal human fibroblasts. Tissue factor activity of cells incubated with trypsin ( $\square$ ) or saline $(O)$ is compared to cell viability during trypsin digestion $(\bullet)$.

to maximize the viability of the suspended cells. For both the normal fibroblasts and the WISH cells, trypsin treatment resulted in the highest cell viability. With WISH cells the viability was greater than $90 \%$ whereas for fibroblasts the viability was consistently above $95 \%$. Scraping of the cell monolayer gave approximately $85 \%$ viable cells with the WISH cells and $30 \%$ viable cells with fibroblasts. Treatment with $0.01 \mathrm{M}$ EDTA in saline resulted in $75 \%$ viable cells for the WISH cells and was ineffective at releasing the fibroblasts from the monolayer.

Fibroblasts, grown in glass bottles for approximately $20 \mathrm{~h}$ in adsorbed serum media, were lifted from the glass by the brief trypsin treatment as described in Methods. After washing and centrifugation, the cells

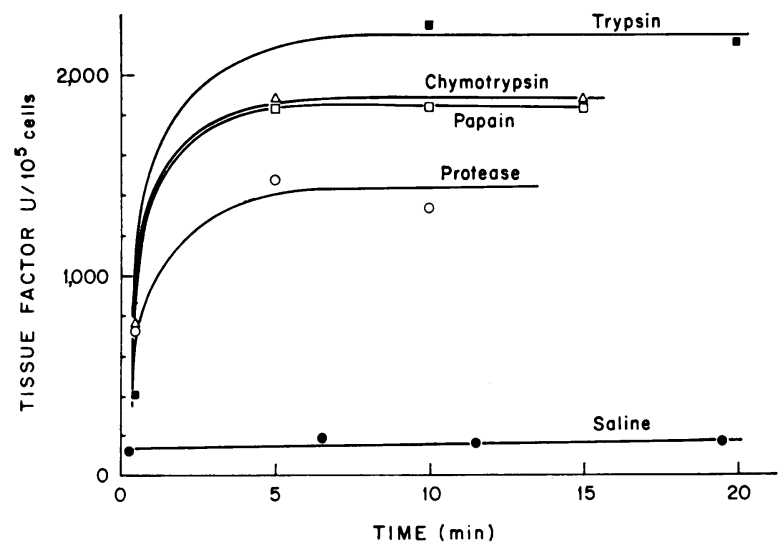

FIGURE 5 Enhancement of the apparent tissue factor activity of suspended fibroblasts by proteolytic treatment. The effect of $0.0025 \%$ trypsin $(\mathbb{\square}), 0.00125 \%$ chymotrypsin $(\triangle)$, $0.01 \%$ papain $(\square), 0.001 \%$ protease $(O)$, or saline $(\bullet)$ on the apparent tissue factor activity level is given. were resuspended in a $0.0025 \%$ trypsin solution. Fig. 4 shows the effect of further trypsin treatment on both cell viability and the apparent tissue factor activity. While the cells showed no loss of viability during this treatment, the level of tissue factor activity increased more than sixfold above that of cells suspended in saline. A number of proteolytic enzymes, in addition to trypsin, were capable of enhancing the apparent tissue factor level of suspended fibroblasts (Fig. 5). With each of these enzymic treatments, there was no loss of cell viability during the time activity was increasing. In 19 complete experiments, trypsin enhanced tissue factor activity 5.17 -fold \pm 1.77 (SD).

Although the general proteases enhanced tissue factor activity in both the cell types studied, a number of enzymes with limited substrate specificity (plasmin, collagenase, elastase, hyaluronidase, thrombin, and $\beta$-galactosidase) had no effect on the apparent tissue factor activity of trypsin-suspended fibroblasts.

Using a crude commercial preparation of neuraminidase from $\mathrm{Cl}$. perfringens, we observed a large increase in the apparent tissue factor activity level; this enhancement of activity was accompanied by a virtually complete loss of cell viability as measured by trypan blue exclusion. After purification by affinity chromatography, however, equivalent amounts of enzymes, as measured by the release of sialic acid from bovine submaxillary gland mucin, failed to enhance the tissue factor level of either fibroblasts or WISH cells.

The established cell line of WISH amnion cells, when grown and dispersed with trypsin in the same manner as the fibroblasts, also showed similar increases in tissue

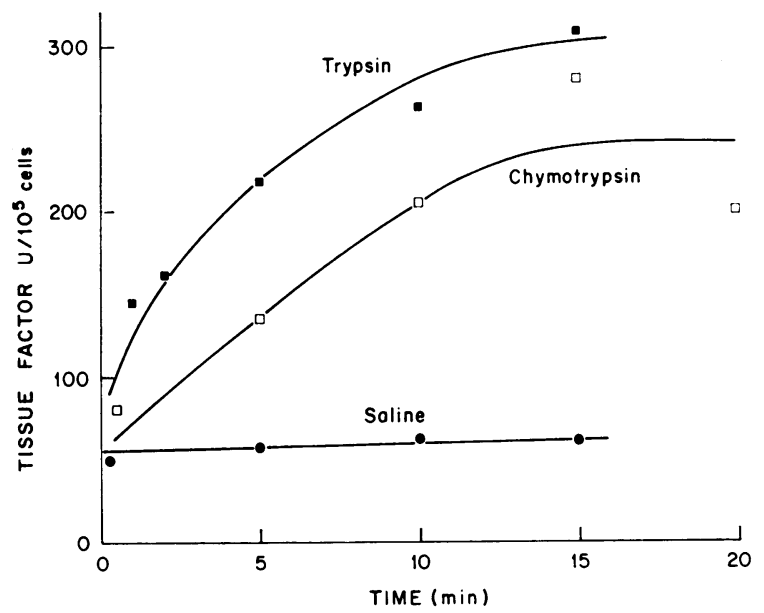

FIGURE 6 Development of tissue factor activity in suspended WISH aminon cells. $0.0025 \%$ trypsin ( $\boldsymbol{\square})$ and $0.00125 \%$ chymotrypsin ( $\square$ ) each enhance the activity of cells previously suspended by brief trypsinization. If the suspended cells are incubated in saline (๑), no change in activity is observed. 
factor activity upon further enzymic proteolysis (Fig. $6)$. In this experiment, the viability of the cells after trypsin suspension was approximately $92 \%$, and no decrease in either cell viability or cell number was observed during subsequent proteolytic treatment.

In all of these studies the enzyme concentrations employed are low enough so that they do not alter the apparent activity in a standard EDTA-brain tissue factor assay.

Location of tissue factor-active material after trypsin treatment of intact cells. Next, we sought to determine whether tissue factor remained cell bound or whether the active material was being released from the cells into the supernate during proteolysis. Trypsin-suspended fibroblasts or WISH cells, which had been further trypsinized as described above, were centrifuged to remove the cells from suspension. The cell pellet and the cell-free supernate were assayed for tissue factor activity (Table I). Proteolytic treatment released 93\% of the tissue factor activity from the fibroblasts, whereas $64 \%$ of the activity was separated from the WISH cells. The cell-free supernate was then centrifuged at high speed under conditions known to remove tissue factor lipoprotein from suspension (39). This resulted in the complete removal of tissue factor activity from the cell-free supernate (Table I). Under the conditions used in these experiments, WISH cells consistently showed recoveries of activity of about $150 \%$; this phenomenon has not been investigated.
TABLE I

Distribution of Tissue Factor from Trypsin-Treated Cells upon Centrifugation

\begin{tabular}{lccc}
\hline & $\begin{array}{c}\text { Incubation } \\
\text { mixture } \\
\text { before } \\
\text { centrifu- } \\
\text { gation }\end{array}$ & $\begin{array}{c}\text { Cell } \\
\text { pellet }\end{array}$ & $\begin{array}{c}105,000 \mathrm{~g} \\
\text { pellet of } \\
\text { cell-free } \\
\text { supernate }\end{array}$ \\
\hline $\begin{array}{l}\text { Fibroblasts } \\
\text { Tissue factor units }\end{array}$ & 789 & 65 & 847 \\
$\begin{array}{l}\text { \% total activity } \\
\text { WISH }\end{array}$ & 100 & 8.2 & 107.3 \\
$\begin{array}{l}\text { Tissue factor units } \\
\text { \% total activity }\end{array}$ & 156 & 94 & 169 \\
\hline
\end{tabular}

A cell suspension was incubated for 30 min with $0.0025 \%$ trypsin in Saline A/HEPES. The suspension was assayed for tissue factor and was then subjected to centrifugation at $800 \mathrm{~g}$ for $5 \mathrm{~min}$. The cell pellet was resuspended and was reassayed for tissue factor. The cell-free supernate was centrifuged at $105,000 \mathrm{~g}$ for $60 \mathrm{~min}$. The pellet from this centrifugation was resuspended and assayed. The $105,000 \mathrm{~g}$ supernate had no tissue factor activity.

Effects of trypsin treatment on the release of cellular enzymes. Although there was no decrease in trypan blue cell viability, we studied the release of several cellular enzymes from WISH cells during trypsin treatment to determine if a loss of cellular integrity was necessary for expression of tissue factor activity. The

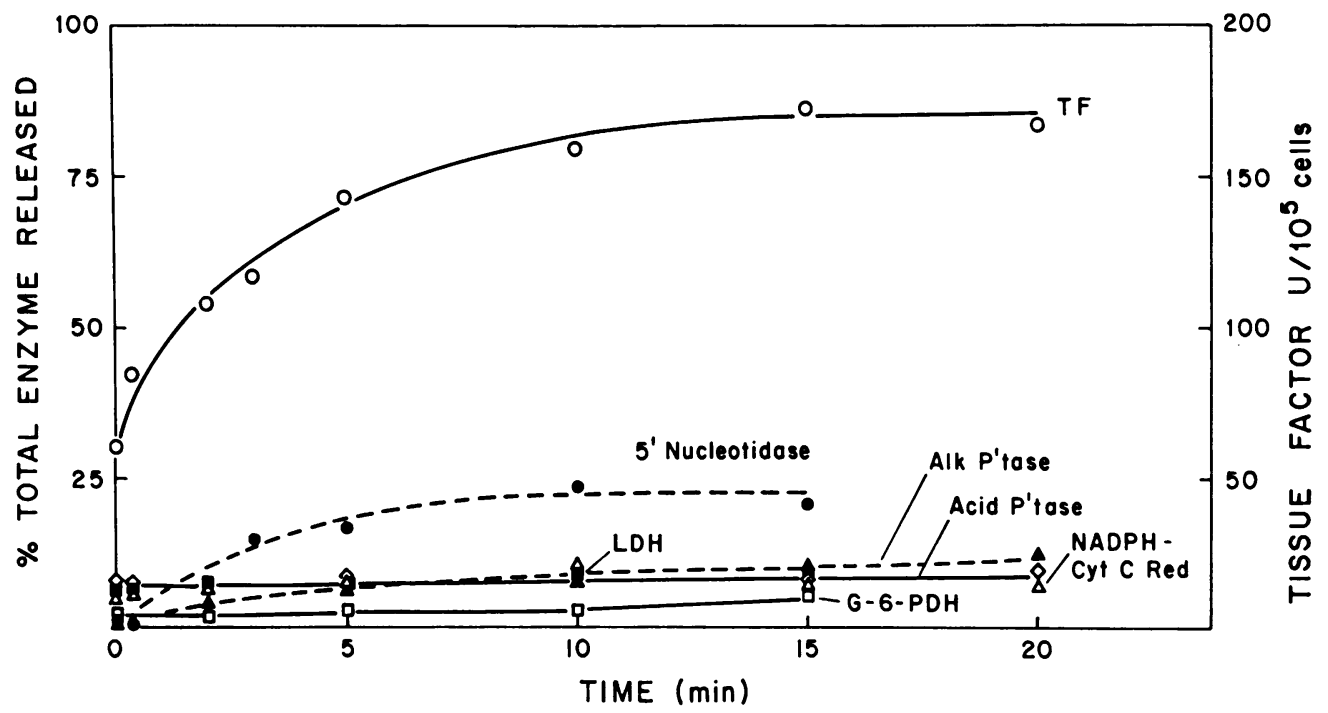

Figure 7 Release of tissue factor activity and cellular enzymes into a cell-free supernate during $0.0025 \%$ trypsin proteolysis of WISH amnion cells. Tissue factor $(O)$ is expressed as the amount of activity in the suspension; $5^{\prime}$-nucleotidase $(\bullet)$, alkaline phosphatase $(\boldsymbol{\Delta})$, acid phosphatase $(\diamond)$, NADPH-cytochrome $c$ reductase $(\triangle)$, lactate dehydrogenase $(\boldsymbol{\square})$, and glucose-6-phosphate dehydrogenase ( $\square$ ) are expressed as the amount in the cell free supernate of the tryptic digest compared to that after sonication of the cells. 

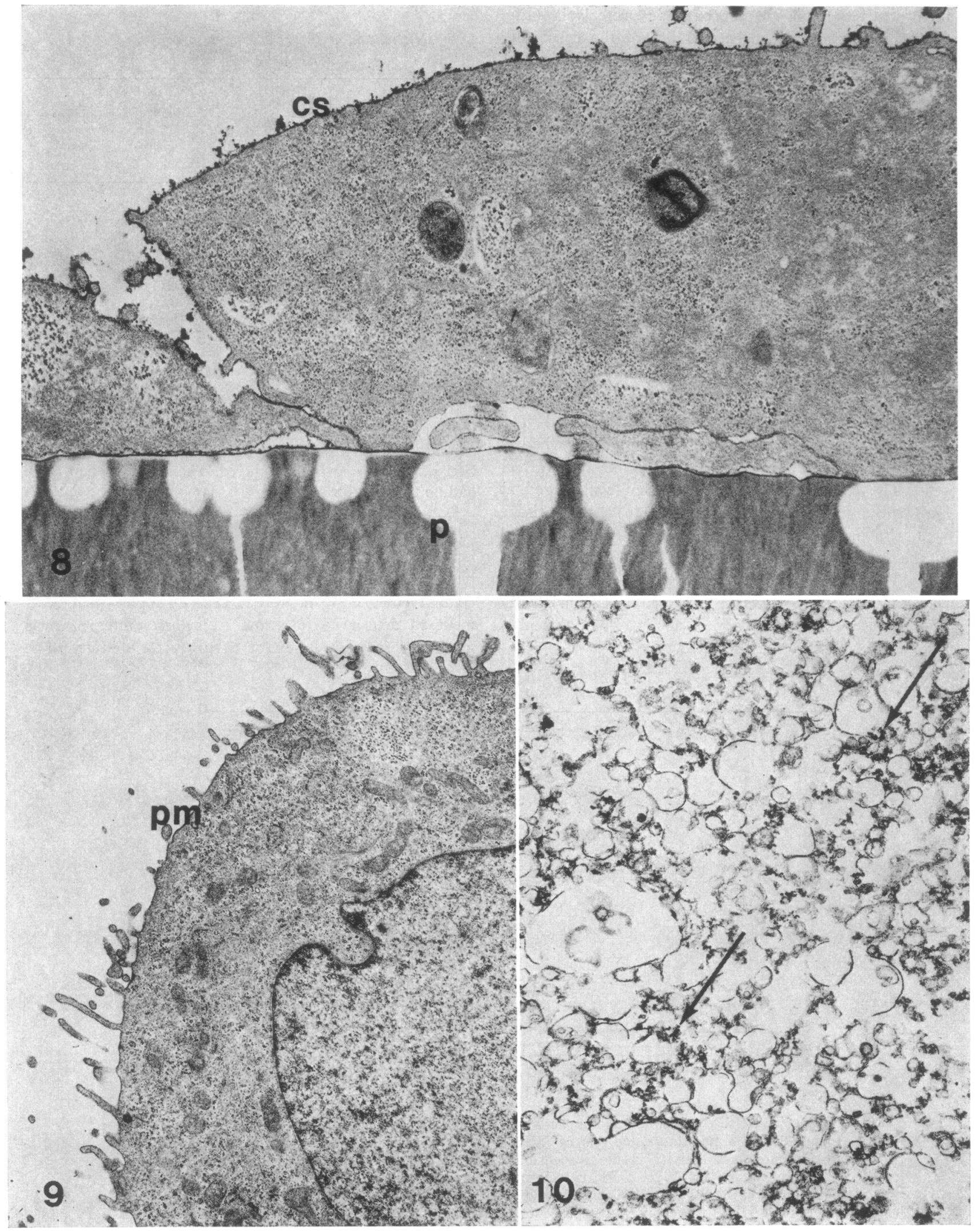

820 J. R. Maynard, C. A. Heckman, F. A. Pitlick, and Y. Nemerson 
levels of soluble cytoplasmic enzymes (lactate dehydrogenase [40] and glucose-6-phosphate dehydrogenase [41]), a lysosomal enzyme (acid phosphatase [42]), and an endoplasmic reticulum-bound enzyme (NADPHcytochrome $c$ reductase [26]) all showed negligible increases during the course of trypsin proteolysis (Fig. 7 ). The levels of two plasma membrane-bound enzymes, 5 -nucleotidase (43) and alkaline phosphatase (44), showed increases to $15-25 \%$ of the total enzymatic content in cells disrupted by sonication (Fig. 7) or freeze-thawing; in contrast, $70 \%$ of the tissue factor activity is expressed under these conditions.

Effects of trypsin treatment on the cell-surface coat. The cultured cells were also examined by electron miroscopy paying particular attention to the morphology of the surface coat. The WISH amnion cells had a ruthenium red-positive layer approximately 10-15 nm thick on the cell surface exposed to the culture medium (Fig. 8); at high magnification, this coat appears to be highly irregular.

A thinner layer of material was apparent on the cellular surface apposed to the petri dish. Microvillar projections on both cell surfaces were common. The decreased staining of the cellular surface attached to the petri dish in these experiments could be due either to a thinner layer of cell surface material or to permeation barriers preventing the diffusion of ruthenium red near the petri dish. To distinguish between these possibilities, cells were also processed with periodate to demonstrate the vicinal hydroxyl groups characteristic of saccharides. Because this reaction was performed after the cells were thin sectioned, differential access of the upper surface to the reagents was obviated, but a heavier deposition of the reaction product on the cellular surface facing the medium was still observed (not illustrated).

The cells were examined in a similar manner immediately after they had been lifted according to the techniques described in Methods. These cells had low tissue factor activity and represented the zero time point in Fig. 6; at this time, most of the ruthenium red-positive coat had been lost (not illustrated). After maximal tissue factor activity had been reached with trypsin digestion (the $20 \mathrm{~min}$ point on Fig. 6), the cells were examined again by electron microscopy; little of the ruthenium red coat remained. Apart from the loss of this material, no morphological changes were noted, thus supporting the biochemical data on cell viability. In thin sections that were stained with uranyl acetate and lead citrate, the plasma membrane appeared to be intact in such cells (Fig. 9).

A layer of ruthenium red-positive material was also present on the plastic petri dishes (Fig. 8) regardless of whether cells were overlying the plastic in the locality. This dense-appearing layer was thin in areas where cells were closely appressed to the plastic dish but thicker and more irregular in areas where cells were not closely appressed. By examining the surfaces of the petri dishes after ruthenium red staining, it was found that a uniform ruthenium red-staining layer approximately $6 \mathrm{~nm}$ in thickness was present on the dish alone both in the presence and absence of culture medium containing serum. The surfaces of dishes from which the cells had been removed with trypsin had a uniform layer similar to that of untreated petri dishes.

Nature of the material released by trypsin proteolysis. When trypsin-suspended WISH cells were further trypsinized as described above, over $80 \%$ of the tissue factor activity of the cell-free supernate could be recovered at the interface after centrifugation on a sucrose cushion. Examination of this fraction by electron microscopy showed that it was composed of ruthenium red-positive particulate material and vesicular fragments (Fig. 10). This fraction contained protein and phospholipid in approximately equal proportions and is being further characterized.

\section{DISCUSSION}

The data presented here confirm those of other investigators who have found that tissue factor occurs in several types of cultured cells. We have extended these observations by showing that intact cells have little or no tissue factor available to initiate the extrinsic system of coagulation. Furthermore, we have demonstrated that tissue factor in the cultured cells becomes available under conditions in which cell viability is

FigURE 8 Ruthenium red staining of WISH amnion cells in situ. The cells were cultured on plastic petri dishes and processed for electron microscopy while still attached to the surface. Both the plastic (p) and the cell surface (cs) stained positively with ruthenium red $(\times 9,000$. Figure 9 Morphology of a trypsin-treated cell. WISH amnion cells were incubated with trypsin for full development of tissue factor activity (20 min point of Fig. 6). In sections stained with uranyl acetate and lead citrate, the plasma membrane (pm) appears to be intact. $(\times 10,000$. $)$

FIGURE 10 Ruthenium red staining of trypsin-released material having tissue factor activity. After WISH amnion tissue factor activity was fully developed by incubation with $0.0025 \%$ trypsin, the cell-free supernate was centrifuged on a sucrose cushion. The interface fraction contained only membranous vesicles and ruthenium red-positive granular material (arrows) resembling the cell-surface coat. $(\times 21,000$. $)$ 
preserved and in which release of intracellular enzymes does not occur.

Radioiodinated factor VII (45) and antibodies to tissue factor apoprotein $(10,11)$ have been used as histochemical markers for localization of tissue factor in situ. In these experiments, factor VII-binding sites, a presumptive marker for tissue factor activity, and the antigen are found in particular abundance at the plasma membrane of endothelial cells. If plasma proteins had ready access to tissue factor in vivo, thrombin would be continuously generated. However, as shown by Ashford and Freiman (46), the endothelium appears to have no coagulant activity in vivo unless traumatized. A protective mechanism must therefore exist, and the results which we have obtained showing that tissue factor is masked in intact cells are consistent with the observations of Ashford and Freiman (46). We interpret our findings as showing that in the model cell systems we have examined, the bulk of the tissue factor is protected and becomes available for initiating the extrinsic system only after the cell surface is perturbed. We emphasize that our findings cannot be directly extrapolated to the living endothelium. In addition to the cell types reported in this paper, we have studied HeLa cells, the MDBK cell line derived from bovine kidney, a cell line derived from rabbit epidermis, and human smooth muscle cells and have observed the same phenomenon of tissue factor dormancy in each. Studies of cultured endothelial cells are now in progress and will be reported later.

The demonstration of the latency of tissue factor was accomplished by using several approaches. When all the components of the tissue factor pathway of coagulation are layered over a washed monolayer of cells, the rate of thrombin generation is low when compared to a similar experiment in which the monolayer is first disrupted by freezing and thawing treatment (Fig. 1). In some experiments, up to 100 -fold enhancement of the available tissue factor has been observed. Qualitatively similar results have been obtained by studying cells lifted from their growth support by short tryptic digestion. In this instance, 6-10-fold activation has been observed. The lower enhancement in this series of experiments is almost certainly due to the partial activation of tissue factor which occurs during the lifting procedure. In a third series of experiments, trypsin was added to a monolayer, and samples were removed at intervals. We found that the appearance of tissue factor activity lagged considerably behind the rate of appearance of detached cells. From these experiments we conclude that sites of attachment of the cells to the glass are either more susceptible to tryptic attack or that tissue factor is physically less accessible to the enzyme. The activating proteolysis was not, however, restricted to trypsin-sensitive bonds. Incubation with chymotrypsin, papain, or a nonspecific bacterial protease also led to a rapid increase in the tissue factor activity of suspended fibroblasts (Fig. 5). Similarly, both trypsin and chymotrysin enhanced the apparent level of tissue factor in suspended WISH cells (Fig. 6).

Incubation of cells with enzymes of more restricted specificity, however, was without effect; plasmin, thrombin, collagenase, elastase, hyaluronidase, and $\beta$-galactosidase were inert. Crude neuramindase ( $\mathrm{Cl}$. perfringens) activated the cells, but when the enzyme was purified by affinity chromatography (23), no effects on the tissue factor activity were observed.

The fact that many different proteolytic enzymes increase the apparent activity of the cells suggests that tissue factor may be masked by a protective coat on the cell surface $(1,15)$. Further evidence that this may be the case was gathered from the observation that after incubation with trypsin, approximately $69 \%$ of the activity of WISH cells was present in a cellfree low-speed supernate (Table I). It should be noted that while this material is released from the cells, it is not soluble and, like all other active forms of tissue factor, it sediments when centrifuged at 105,000 g (Table I). Similar data were obtained with fibroblasts with over $90 \%$ of the activity being released into the cell-free supernate.

To exclude the possibility that the release of tissue factor was the result of leakage from intracellular sites, the release of several enzymes from the cells was followed during the course of trypsinization. Neither enzymes associated with organelles nor soluble enzymes were released into the cell-free supernate over the time-course studied. Moderate amounts of two plasma membrane markers, 5'-nucleotidase and alkaline phosphatase, however, appeared in the cell-free supernates during the experiment. Although the release of these enzymes was considerably less than the release of tissue factor (Fig. 3), this finding suggests that some disruption of plasma membrane does occur. Nonetheless, the release of tissue factor from the cells while viability is maintained and no loss of intracellular enzymes has occurred is strong evidence for the cell-surface localization of tissue factor.

A possibility that cannot be experimentally excluded, although it seems unlikely, is that trypsin stimulates these cells to specifically secrete tissue factor. The fact that trypsin has been shown to release cell-surface glycoprotein from Chinese hamster ovary cells (47), Erlich ascites carcinoma cells (48) and mouse mammary adenocarcinoma cells (49), and not to release such intracellular components as heparan sulfate (16) and nucleic acid (50), argues against trypsin-stimulated release of tissue factor from intracellular sites. Even if it 
were shown to be the case, however, the observation that tissue factor can be released from essentially intact, viable cells would still be valid, and the concept of the latency of tissue factor would be equally tenable.

During the course of tryptic digestion, a significant proportion of the cellular tissue factor is released (Table I). This material is not soluble and contains considerable amounts of phospholipid (data not presented). The cells were also studied by electron microscopy during the course of trypsinization as was the material released from the cells. Ruthenium red, a stain thought to selectively localize acid mucopolysaccharides (51), has been used to visualize the surface coat of endothelial cells (15). Using this stain on the cultured cells, we find that most of the ruthenium red stainable material on the cell surface can be removed before tissue factor is unmasked. Further trypsinization releases tissue factor from the cells. When this material was centrifuged on a sucrose cushion, the activity was concentrated at the interface. Examination of this material revealed ruthenium red-staining fibrillar material free and in association with vesicles. Although it seems likely, owing to the lipid requirement of tissue factor, that the active material is vesicular, it is not possible to assign the activity to a unique morphological entity.

Since less than $25 \%$ of plasma membrane enzyme markers are released during trypsinization whereas 40$70 \%$ of the tissue factor activity is found in this fraction, tissue factor appears to be located somewhere between the cell-surface coat and the plasma membrane. Clearly, total cell disruption is not necessary for expression of tissue factor activity, and the degree to which cells must be damaged to initiate blood coagulation may be significantly less than previously thought.

\section{ACKNOWLEDGMENTS}

The technical assistance of Mr. Dan Fintel is gratefully appreciated. Doctors Sidonie Silverberg, Jolyon Jesty, and Robert Radcliffe generously supplied the purified coagulation reagents. Dr. Russell Barrnett kindly provided the instruments used for the electron microscopic studies.

This work was supported by grants from the John A. Hartford Foundation and the National Institutes of Health (NHLI 16126).

\section{REFERENCES}

1. Kirk, J. E. 1965. Mucopolysaccharides and thromboplastin in the vessel wall. In Biophysical Mechanisms in Vascular Hemostasis and Intravascular Thrombosis. P. N. Sawyer, editor. Appleton-Century-Crofts Inc., New York. 244-266.

2. Wilner, G. D., H. L. Nossel, and E. C. LeRoy. 1968. Activation of Hageman factor by collagen. J. Clin. Invest. 47 : 2608-2615.

3. Niewiarowski, S., E. Bankowski, and I. Rogowicka. 1965. Studies on the adsorption and activation of Hage- man factor (factor XII) by collagen and elastin. Thromb. Diath. Hacmorrh. 14: 387-400.

4. Nemerson, Y. 1966. The reaction between bovine brain tissue factor and factors VII and X. Biochemistry. 5: 601-608.

5. Williams, W. J., and D. G. Norris. 1966. Purification of a bovine plasma protein (factor VII) which is required for the activity of lung microsomes in blood coagulation. J. Biol. Chcm. 241: 1847-1856.

6. Nemerson, Y., and M. P. Esnouf. 1973. Activation of a proteolytic system by a membrane lipoprotein: mechanism of action of tissue factor. Proc. Natl. Acad. Sci. U.S. A. 70: 310-314.

7. Jesty, J., and Y. Nemerson. 1974. Purification of factor VII from bovine plasma. Reaction with tissue factor and activation of factor X. J. Biol. Chem. 249: 509-515.

8. Milstone, J. H. 1964. Thrombokinase as a prime activator of prothrombin: historical perspectives and present status. Fed. Proc. 23: 742-748.

9. Stemerman, M. B., H. R. Baumgartner, and T. H. Spaet. 1971. The subendothelial microfibril and platelet adhesion. Lab. Invest. 24: 179-186.

10. Zeldis, S. M., Y. Nemerson, F. A. Pitlick, and T. L. Lentz. 1972. Tissue factor (thromboplastin): localization to plasma membranes by peroxidase-conjugated antibodies. Science (Wash. D. C.). 175: 766-768.

11. Stemerman, M. B., and F. A. Pitlick. Tissue factor antigen and blood vessels. Thromb. Diath. Hacmorrh. (Suppl.) 60: 51-58.

12. Zacharski, L. R., E. J. W. Bowie, J. L. Titus, and C. A. Owen, Jr. 1969. Cell-culture synthesis of a factor VIII-like activity. Mayo Clin. Proc. 44: 784-792.

13. Green, D., C. Ryan, N. Malandruccolo, and H. L. Nadler. 1971. Characterization of the coagulant activity of cultured human fibroblasts. Blood J. Hematol. 37 : 47-51.

14. Rickles, F. R., J. A. Hardin, F. A. Pitlick, L. W. Hoyer, and M. E. Conrad. 1973. Tissue factor activity in lymphocyte cultures from normal individuals and patients with classic hemophilia A. J. Clin. Invest. 52: $1427-1434$.

15. Luft, J. H. 1966. Fine structure of capillary and endocapillary layer as revealed by ruthenium red. Fed. Proc. $25: 1,773-1,783$.

16. Kraemer, P. M. 1971. Heparan sulfates of cultured cells. I. Membrane-associated and cell-sap species in chinese hamster cells. Biochemistry. 10: 1437-1445.

17. Silbert, J. E., H. Kleinman, and C. K. Silbert. 1975. Heparin and heparin-like substances of cells. Adv. Exp. Med. Biol. 52: 51-60.

18. Esnouf, M. P., P. H. Lloyd, and J. Jesty. 1973. A method for the simultaneous isolation of factor $\mathrm{X}$ and prothrombin from bovine plasma. Biochem. J. 131: 781789.

19. Bell, W. N., and H. G. Alton. 1954. A brain extract as a substitute for platelet suspensions in the thromboplastin generation test. Nature (Lond.). 174: 880-881.

20. Nemerson, Y., and L. P. Clyne. 1974. An assay for coagulation factor VII using factor VII-depleted bovine plasma. J. Lab. Clin. Med. 83: 301-303.

21. Phillips, H. J. 1973. Dye exclusion tests for cell viability. In Tissue Culture. Methods and Applications. P. F. Kruse, Jr. and M. K. Patterson, Jr., editors. Academic Press, Inc., New York. 406-408.

22. Nemerson, Y. 1968. The phospholipid requirement of tissue factor in blood coagulation. J. Clin. Invest. 47: $72-80$. 
23. Cuatrescasas, P., and G. Illiano. 1971. Purification of neuraminidases from Vibrio cholerae, Clostridium perfringens, and influenza virus by affinity chromatography. Biochem. Biophys. Res. Commun. 44: 178-184.

24. Cuatrecasas, P., and C. B. Anfinsen. 1971. Affinity chromatography. In Methods in Enzymology. W. B. Jakoby, editor. Academic Press, Inc., New York. 22: 345-378.

25. Warren, L. 1959. The thiobarbituric acid assay of sialic acids. J. Biol. Chem. 234: 1971-1975.

26. Jones, P. D., and S. J. Wakil. 1967. A requirement for phospholipids by the microsomal reduced diphosphopyridine nucleotide-cytochrome $c$ reductase. J. Biol. Chem. 242: 5267-5273.

27. Williams, C. H., Jr., and H. Kamin. 1962. Microsomal triphosphopyridine nucleotide-cytochrome $c$ reductase of liver. J. Biol. Chem. 237: 587-595.

28. Young, I. I. 1958. Serum 5'-nucleotidase: characterization and evaluation in disease states. Ann. N. Y. Acad. Sci. 75 : 357-362.

29. Chen, P. S., T. Y. Toribara, and H. Warner. 1956. Microdetermination of phosphorus. Anal. Chem. 28: 1756-1758.

30. Bergmeyer, HU, E. Bernt, and B. Hess. 1965. Lactic dehydrogenase. In Methods of Enzymatic Analysis. HU Bergmeyer, editor. Academic Press, Inc., New York. 2nd edition. 736-741.

31. Lohr, G. W., and H. D. Waller. 1965. Glucose-6-phosphate dehydrogenase. In Methods of Enzymatic Analysis. HU Bergmeyer, editor. Academic Press, Inc., New York. 2nd editor. 744-751.

32. Linhardt, K., and K. Walter. 1965. Phosphatases (phosphomonoesterases). In Methods of Enzymatic Analysis. HU Bergmeyer, editor. Academic Press, Inc., New York. 2nd edition. 779-787.

33. Keen, L. N., R. Reynolds, W. L. Whittle, and P. F. Kruse, Jr. 1973. Vertical sectioning. B. Cells in plastic flasks. In Tissue Culture Methods and Applications. P. F. Kruse, Jr. and M. K. Patterson, editors. Academic Press, Inc., New York. 448-451.

34. Luft, J. H. 1971. Ruthenium red and violet. I. Chemistry, purification, methods of use for electren microscopy and mechanism of action. Anat. Rcc. 171: 347-358.

35. Spurr, A. R. 1969. A low-viscosity epoxy resin embedding medium for electron microscopy. J. Ultrastruct. Res. $26: 31-43$.

36. Coulter, H. D. 1967. Rapid and improved methods for embedding biological tissues in Epon 812 and Araldite 502. J. Ultrastruct. Res. 20: 346-355.

37. Reynolds, E. S. 1963. The use of lead citrate at high
$\mathrm{pH}$ as an electron-opaque stain in electron microscopy. J. Cell Biol. 17 : 208-212.

38. Thiéry, J. P. 1967. Mise en évidence des polysaccharides sur coupes fines en microscopie électronique. J. Microsc. (Paris). 6: 987-1018.

39. Pitlick, F. A., and Y. Nemerson. 1970. Binding of the protein component of tissue factor to phospholipids. Biochemistry. 9: 5,105-5,113.

40. LePage, G. A., and W. C. Schneider. 1948. Centrifugal fractionation of glycolytic enzymes in tissue homogenates. J. Biol. Chem. 176: 1021-1027.

41. White, A., P. Handler, and E. L. Smith. 1968. Principles of Biochemistry. McGraw-Hill Book Company, New York. 4th edition.

42. Straus, W. 1967. Lysosomes, phagosomes, and related particles. In Enzyme Cytology. D. B. Roodyn, editor. Academic Press, Inc., New York. 239-319.

43. DePierre, J. W., and M. L. Karnovsky. 1974. Ectoenzyme of granulocytes : 5 '-nucleotidase. Scicnce (Wash. D. C.). 183: 1096-1098.

44. Emmelot, P., C. J. Bos, E. L. Benedetti, and P. H. Rümke. 1964. Studies on plasma membranes. I. Chemical composition and enzyme content of plasma membranes isolated from rat liver. Biochim. Biophys. Acta. 90: 126-145.

45. Goldenfarb, P. B., F. A. Pitlick, and Y. Nemerson. 1973. Factor VII : a biological probe for initiation sites of blood coagulation. J. Clin. Invest. 52: 34a. (Abstr.)

46. Ashford, T. P., and D. G. Freiman. 1968. Platelet aggregation at sites of minimal endothelial injury. An electron microscopic study. Am. J. Pathol. 53: 599-607.

47. Kraemer, P. M. 1967. Regeneration of sialic acid on the surface of chinese hamster cells in culture. II. Incorporation of radioactivity from glucosamine-1- ${ }^{14} \mathrm{C} . J$. Cell. Physiol. 69: 199-208.

48. Langley, O. K., and E. J. Ambrose. 1967. The linkage of sialic acid in the Ehrlich ascites-carcinoma cell surface membrane. Biochem. J. 102: 367-372.

49. Codington, J. F., B. H. Sanford, and R. W. Jeanloz. 1972. Glycoprotein coat of the TA3 cell. Isolation and partial characterization of a sialic acid containing glycoprotein fraction. Biochemistry. 11: 2559-2564.

50. Snow, C., and A. Allen. 1970. The release of radioactive nucleic acids and mucoproteins by trypsin and ethylenediaminetetraacetate treatment of baby-hamster cells in tissue culture. Biochem. J. 119: 707-714

51. Luft, J. H. 1971. Ruthenium red and violet. I. Chemistry, purification, methods of use for electron microscopy, and mechanism of action. Anat. Rec. 171: 347-368. 